\title{
Genocide Denial: A Form of Evil or a Type of Epistemic Injustice?
}

Imge Oranlı

Lecturer of Philosophy, Koc University

\begin{abstract}
In this paper, I bring together the philosophical scholarship on evil and the literature on "epistemic injustice" in order to assess effective vocabulary to understand the phenomenon of genocide denial. I use the term "denial" to denote the discursive political tactic that makes the evil of genocide invisible. Adi Ophir's discussion of "two orders of evil" allows us to consider genocide denial as a form of evil. For what Ophir identifies as a secondorder evil, another stream of scholarship suggests the term "epistemic injustice." This latter literature can also be deployed effectively in treating the question of genocide denial, insofar as it provides an interdisciplinary approach rather than a strictly philosophical one. Epistemic injustice scholars focus on different types of unfair treatment in the realm of knowledge-production, and they agree that exclusion, silencing, invisibility and distorted representation are major forms of epistemic injustice. I argue that both scholarships are crucial to draw out conceptual frameworks for understanding the specific case of genocide denial. Furthermore, I think that interdisciplinary approaches informed by the social sciences are essential to map out the real life implications of the injustices that are implemented through denial.
\end{abstract}

Keywords: Denial, Genocide Denial, Form of Evil, Theory of Evil, Epistemic Injustice.

\section{Introduction}

From a psychoanalytic perspective, denial is "a defense that originates in the child's efforts to rid himself or herself of unpleasant perceptions of the outside world." (Moses, 1989, p. 288). In the case of genocide denial, the perpetrator group and its ideological supporters wish to eliminate the culpability of the genocidal act. Although, the psychoanalytical definition underscores an important aspect of the phenomenon of genocide denial, namely, the desire to eliminate responsibility, another kind of vocabulary is needed to capture the systematic and political nature of genocide denial. To highlight this systematic and institutional aspect of denial and to distinguish it from the psychoanalytic employment of the term, I consider genocide denial as an ideologically supported political lie (as distinguished from pragmatic and occasional political lies). Such an attempt views genocide denial as a discursive political tactic (or strategy) with a goal to make invisible a massive scale wrongdoing (i.e., the atrocities that constitute the genocide) through the implementation of systematic lies. ${ }^{1}$

This paper is interested in understanding the phenomenon of genocide denial through different scholarly approaches that bring forth the ethical implications of this systematically produced political act. It is my contention that the philosophical scholarship on evil and the interdisciplinary literature on epistemic injustice provide effective vocabulary for understanding this phenomenon. The paper discusses why these two areas of scholarship are resourceful and how they can contribute to the conceptual framework in understanding this phenomenon. First, I clarify what genocide denial is and how it is produced and distributed by focusing on a current example: The Turkish denial of the Armenian Genocide. Secondly, I briefly consider two philosophical approaches, Adi Ophir's and Claudia Card's, which are useful for situating genocide denial as a form of evil. These treatments discuss the question of evil as a social phenomenon and not as a problem of the individual-which has been the common tendency in the Western philosophical tradition. This is why, I find their theories accommodating for

\footnotetext{
1 This definition suggests that we are not within the psychoanalytical domain but in the political domain where denial is understood through its political function as used by the perpetrator group. There are also cases in which the survivor group engages in collective denial. See "Some Observations on denial and Avoidance in Jewish Holocaust and Post-Holocaust Experience" (Klein and Kogan, 1989). Correlations drawn between the everyday psychic denial of the neurotic person and the denial of Holocaust survivors have shown that in both cases denial can be considered as a defense mechanism; therefore, it has a positive function for survival. For a further discussion of the relation between psychic and social denial, see The Politics of Denial (Milburn and Conrad, 1996).
} 
addressing this peculiar form of social evil. And finally, I examine the literature on epistemic injustice. Epistemic injustice scholars focus on different types of injustices in the realm of knowledge-production. They claim that exclusion, silencing, invisibility and distorted representation are major forms of epistemic injustice. I argue that actively implanted collective ignorance is a type of epistemic injustice that is suitable for understanding the phenomenon of genocide denial. In discussing how the collective denial of genocide can be viewed as an actively implanted ignorance, I use Linda Martin Alcoff's essay "Epistemologies of Ignorance" (Alcoff, 2007) together with Gaile Pohlhaus' taxonomy of three types of epistemic injustice (Pohlhaus, 2017). According to my view, genocide denial can be considered as a form of epistemic injustice because the existence of collective denial requires a social and political environment where systematic distribution of ignorance takes place.

\section{What is Genocide Denial?}

The concept of denial suggests that there are at least two different ways to understand what has happened: we can either accept the ethical implications of the event in question or we can cast a doubt to the existence of the event, and thereby, attempt to silence its ethical implications. Michael A. Milburn and Sheree D. Conrad suggest that, "understanding the history and process of denial as a psychological mechanism is essential to a comprehensive understanding of current public opinion, political leaders, and events" (Milburn and Conrad, 1996, p. 13). From their perspective, denial should be viewed as a psychic phenomenon that has political implications. Although I am in agreement with their approach, in this essay, I examine denial as a political phenomenon because of its particular political and ideological goal: rejecting the existence of a willfully administered atrocity.

In the case of genocide denial, denial operates on the assumption that we may not know the whole truth about a past historical event. Production, distribution and circulation of conflicting narratives is one of the most favored techniques of genocide denial. Therefore, casting doubt about how the event has occurred is one of the most effective ways to implement genocide denial. Genocide denial is different from other forms of denial (e.g. in interpersonal relations), because, here, denial is not merely a negation of a fact, but also a discursive act that continues to systematically harm the survivors. Systematically silencing the existence of an intended wrongful act is the continuation of the genocidal act because it aggravates the harm. Denial not only refers to the act of replacing "truth,", but also the will to create another regime of truth. To focus on this point, Hannah Arendt's essay "Lying in Politics" is useful; here she considers lying not as a defect in politics but as a way to begin something new. She states that lying is a political act in and of itself. She writes,

[...] let us remember that the lie did not creep into politics by some accident of human sinfulness. Moral outrage, for this reason alone, is not likely to make it disappear. The deliberate falsehood deals with contingent facts; that is, with matters that carry no inherent truth within themselves [...]. Facts need testimony to be remembered and trustworthy witnesses to be established [...]. From this, it follows that no factual statement can ever be beyond doubt [...]. It is this fragility that makes deception so easy up to a point, and so tempting." (Arendt, 1972, p. 6)

According to Arendt's above assessment, what makes political lie such a powerful political tool is the fragility of historical facts. These facts are open to interpretation, because they carry no truth within themselves. Following from this, a certain atrocious historical event or series of events can be categorized as genocide only on the condition that it meets international consensus. It is often this lack of international consensus that helps governments in their attempts to distort the meaning of historical events.

\section{Recent examples: Various tactics of Genocide Denial}

One of the long-standing, if not the longest, example of genocide denial is the Turkish denial of the Armenian Genocide. It is still being officially denied by the Turkish government, and many journalists and other public and political figures in Turkey have long been facing criminal charges for speaking about the Armenian Genocide. Most recently, in 2007, the Armenian journalist Hrant Dink was assassinated due to openly and publicly speaking about the Armenian Genocide. ${ }^{1}$ Although his assassination backlashed and increased knowledge and awareness within the Turkish public, there is still a large population

\footnotetext{
${ }^{1}$ For a further discussion, see "Coming to terms with a difficult past: the trauma of the assassination of Hrant Dink and its repercussions on Turkish national identity" (Türkmen-Dervişoğlu, 2013).
} 
which continues to deny the existence of an intended and systematic atrocity against the Ottoman Armenians. ${ }^{1}$ The common opinion in Turkey is that during the WWI, Armenians were forcefully deported from the Ottoman land, because they were considered a security threat. This narrative does not uphold any government official to be responsible for the atrocities committed during the time of deportations. Nor does it recognize the massive number of Armenian deaths, abduction of women and children, and confiscation of Armenian property. In some versions of this false narrative, even the legislation for deportation is denied, and the story is inverted by claiming that it was the Armenians who killed the Turks.

Since the foundation of the Turkish Republic in 1923, many different versions of these false narratives have been distributed by the Turkish state to account for the events of 1915. According to Raymond Kévorkian's detailed analysis, which depicts the situation of Armenians in the Eastern provinces of Ottoman Turkey during 1915, the fabrication of false narratives was the number one strategy to mobilize the Muslim population against the Armenians (Kévorkian, 2011). These narratives mobilized locals, who destroyed Armenian property, abducted women and children, and massacred men (Kévorkian, 2011, p. 239). Kévorkian's study suggests that the implementation of political lies was already taking place before and during the genocidal act and were not only put into effect after the event.

For the newly born Turkish Republic denial had created a world founded upon a political lie. This point brings us back to the question of the function of political lies, as stressed by Arendt. Cathy Caruth (2010) agrees with Arendt in the productive function of lying. She writes, "the lie does not appear in the political realm only as the denial of the historical acts of the past [...];" through the very act of denial a new beginning is assumed (Caruth, 2010, p. 82). In the case of the Turkish Republic, the official narrative depicting the events of 1915 presents an extreme and unique example of lying. According to Roger W. Smith, "in no other instance has a government gone to such extreme lengths to deny that a massive genocide took place" (Smith, 2006, p. i). As a result, the Armenian Genocide became the 'forgotten genocide' according to Hovanissian (Hovanissian, 1994). To make this possible, there have been various attempts and maneuvers by the Turkish government. In what follows, I briefly provide a few examples.

Marc Mamigonian draws attention to the most powerful tactic of denial used by the American tobacco industry during the 1950's, which was also used in Turkey's denialist campaign, namely, manufacturing doubt about scientific evidence (Mamigonian, 2013). When the tobacco industry was faced with the scientific evidence that smoking was a number one cause of lung cancer, it established the Council for Tobacco Research that was designed with the specific intent of manufacturing doubt. Mamigonian underscores that it was the same Hill \& Knowlton PR Company that worked for Turkey in its denial campaign. Hill \& Knowlton devised a new method for denying the genocide: manufacturing doubt about historical evidence. Mamigonian writes that, "a key element of Turkey's long-range plan was to expand upon the small group of American scholars [...], to cultivate academics who could produce [...] genocide-denying scholarship" (Mamigonian 2013). To this end, in 1983 Turkey established the Institute of Turkish Studies in Washington D.C. with a grant of three million dollars from the Turkish state. Another exampleis provided by Ronald Grigor Suny and Fatma Müge Göçek (2011), who stress that "[i]n the fall of 2000, when the U.S. House of International Relations Committee voted on a resolution recognizing mass killing of Armenians in the Ottoman Empire as genocide, Turkish money financed lobbyists in Washington to work against [it]" (p. 4). They also note that the Turkish state intensified "its campaign of denial of the genocide" when a series of workshops were organized between Armenian and Turkish scholars on the question of the Armenian Genocide.

Most interesting example, however, can be read through the article drafted by scholars, Roger W. Smith, Eric Markusen and Robert Jay Lifton. This article entitled, "Professional Ethics and the Denial of Armenian Genocide," portrays an awkward case of genocide denial. The article opens with the following lines:

[...] suppose that one receives a letter from the Turkish ambassador to the United States rebuking one's scholarship because one has written about what the ambassador refers to as "the so-called Armenian genocide, allegedly perpetrated by the Ottoman Turks during the First World War." Suppose that, inadvertently, the envelope also contains an internal memorandum written by the executive director of what claims to be a non-political, scholarly institute and that memorandum

\footnotetext{
1 On that day, two hundred fifty Armenian men, including intellectuals, community leaders and members of the parliament were arrested in Constantinople (Istanbul) by the ruling Ottoman government, composed of members of the Committee of Union and Progress. Many of those who were arrested were killed. In the following months of 1915, the leading members of the Committee of Union and Progress issued an order regarding the deportations of Armenians living in West and East Anatolia to Der Zor, a deserted area in Syria.
} 
reveals much about the mentality of those who engage in denial of the Armenian Genocide. What then? (Smith et al., 1999, p.271)

The above remarks belong to Smith, Markusen and Lifton, each of whom received (in different occasions) a letter from the Turkish Ambassador questioning their academic credibility, because they have written about the Armenian Genocide. The above-quoted article was published in Spring 1995 in the Holocaust and Genocide Studies journal by these three scholars after Lifton received a letter from the Turkish Ambassador.

In his 1986 book, The Nazi Doctors, Lifton had discussed the important role played by the Turkish doctors in the Armenian Genocide. According to Lifton, Dr. Mehmed Reshid, Dr. Bahaeddin Shakir and Dr. Nazim, were active participants and influential members of the Committee of the Union and Progress-the organization responsible for the Armenian Genocide. One of the doctors had described Armenians as "a cancer, a malignance which looks like a small pimple from the outside, which, if not removed by a skillful surgeon's scalpel, will kill the patient" (Lifton, 1986, p. 489).After the book was published in 1986, four years later, in 1990, Lifton received a letter from the Turkish Ambassador in Washington, Nuzhet Kandemir. In the letter, the Turkish Ambassador had claimed that the events of 1915 do not constitute genocide and that Lifton's scholarly references are weak and cannot support his claim (Smith et al., 1999). Hence, the Turkish Ambassador was questioning the academic credibility of Lifton's claims about the Armenian Genocide by stressing that the subject matter in question is open to interpretation. The most interesting thing about this letter, we are informed, is that it was accompanied by a memorandum, drafted by the Ottoman Historian Dr. Heath Lowry, who was at the time the director of the Turkish Studies in Washington D.C. (Smith et al., 1999). As Mamigonian's above-mentioned article stated, one of the most powerful tactics of denial, implemented by the Turkish government, was to cast doubt through "scholarly" work. The Turkish Ambassador's letter addressing Lifton was drafted by an academic (Dr. Lowry), whose job was to produce scholarly doubt regarding the existence of the Armenian genocide.

This particular letter suggests that the evilness of an event (e.g., the Armenian Genocide) has to be persistently claimed against future denialist attempts. Such cases show us that ontology of evil is precarious in the face of denialist efforts. Hence, the phenomenon of genocide denial reveals an important aspect of the ontology of evil, because it suggests a gap between evil's existence and its public appearance as evil. In other words, the possibility of denying the existence of an evil event testifies to the fact that not all evils that exist appear as evil to the public eye. Arendt's above-mentioned claim, namely, "facts need testimony to be remembered and trustworthy witnesses to be established" (Arendt, 1972, p. 6), warns us against this possibility (of not appearing as evil). As in the case of the Turkish denial of the Armenian genocide, a dominant political group can claim that the event in question does not match the international criteria for what constitutes a genocide. ${ }^{1}$ Through such a denialist discourse, the evil that took place is eradicated from public and cultural memory. Hence, genocide denial is a discursive political tool making possible the political and social disappearance of an evil event. As genocide scholar Roger W. Smith indicates, "denial, unchecked, turns politically-imposed death into a 'non-event': in place of words of recognition, indignation, and compassion, there is, with time, only silence" (Smith, 2006, p. ii.).

\footnotetext{
1 The criteria laid out by the Convention on the Prevention and Punishment of the Crime of Genocide are as follows: 1) Killing members of the group 2) Causing serious bodily or mental harm to members of the group; 3) Deliberately inflicting on the group conditions of life calculated to bring about its physical destruction in whole or in part; 4) Imposing measures intended to prevent births within group; 5) Forcibly transferring children of the group to another group. See "United Nations Office on Genocide Prevention and the Responsibility to Protect." United Nations, www.un.org/en/genocideprevention/genocide.html.
} 
If we consider the phenomenon of genocide and its denial as different forms of evil, as I am suggesting here, we would be assuming a moral framework. There are various moral conceptualizations that can be considered in assessing the evilness of genocide denial, hence it is important to discriminate vocabularies and frameworks that are most effective when one is dealing with the phenomenon of genocide denial. In what follows, I focus on two key scholarships that speak to this concern.

\section{Why is Genocide Denial a Form of Evil?}

I already suggested that genocides need continuous remembrance and claim for recognition. It is my view that two prominent scholarly fields are relevant for understanding the ethical implications of genocide denial. In this section, I focus on one of these fields: philosophical studies on evil.

As one of the prominent scholars of philosophical studies on evil, Adi Ophir suggests that social evils have been understood as a disease in modernity, which can be cured through certain corrective and educational institutions (2005, p. 335-6). According to this Enlightenment view, the common belief maintains that evil is the result of ignorance. The problem with this type of account, according to Ophir, is that those who diagnose these evils do not recognize their own participation in the system of production of evils. Hence, the society at large is assumed to be exempt from participation in systematic wrongdoing. Rather, certain groups and individuals are criminalized and marginalized as the sources of evils within the society. This type of marginalization often targets groups that are minorities (whether sexual, racial, ethnic, religious etc.). The consequence of this kind of approach for understanding social evils is that the source of evil is always misrepresented. To avoid such a misplacement of the origin of social evils, Ophir's account offers two conceptual directions.

First, he coins the term "superfluous evil" in order to establish a domain of wrongdoing that cannot be justified as a means to a further end. He writes, "to justify is to turn evil into something useful for someone, something that takes place in order to achieve or avoid something" (Ophir, 2005 p. 340). The term "superfluous evil" is helpful for understanding the evil of genocide, since genocide, by definition, cannot be considered as a means to an end, as it directly targets the livelihood of a racial or ethnic group. Furthermore, Ophir defines two orders of evil. He writes that, "a first-order evil" is "one that did not find expression," and "a second-order evil" is "one tied to the prevention of expression" (Ophir, 2005, p. 341). Although Ophir himself does not examine genocide denial as a second-order evil, according to his taxonomy, genocide denial can be viewed as a second-order evil, since it is a form of evil that is the result of "prevention of expression." It is important to notice that these two orders of evil depend on and enable each other. The second order evil aims to perpetuate the first order evil by making sure that the harm of genocide continues to find no expression.

Another philosopher of evil, Claudia Card (2005), points out one of the key questions that scholars face: "What can make evils difficult to recognize?" (p. 3) As I have suggested above, the political tactic of denial is one of the ways through which an evil event loses recognition. According to Card's theory, one of the reasons promoting the act of denial is that "perpetrators commonly do not understand their deeds as atrocities" (Card, 2005, p. 9). In reference to a psychological experiment conducted by Roy F. Baumeister, Card states that perpetrators often distort the results to make it seem not as bad as it actually is. This situation is referred to as the "magnitude gap," where the victims' perception of the suffering is always greater than the perpetrators'. She concludes that this results in a distorted understanding of the suffering that is experienced by the victims because many evils do not appear as atrocious to the public (Card, 2005, p.10). Card's response to this paradox (i.e., magnitude gap) is to suggest that we begin our inquiry from the perspective of the suffering group or individual. If we apply this suggestion to the Turkish-Armenian case, we can infer that sharing the narratives of the survivors and listening to the stories of their descendants can be a productive way to make the Turkish public recognize the suffering that was endured by the victims (at least up to a point). The problem with this suggestion however is that when a national culture is steeped in collective denial, the narratives of the survivors will appear as lies, which is unfortunately the dominant opinion in Turkey today.

\section{Epistemic Injustice and Genocide Denial}

Another theoretical approach that I find useful for addressing the question of genocide denial is the new emerging scholarship on epistemic injustice. Routledge Handbook of Epistemic Injustice defines epistemic injustice by referring "to those forms of unfair treatment that relate to issues of knowledge, understanding, and participation in communicative practices" (Kidd et al., 2017, p. 1). This scholarship brings together a variety of disciplines within and outside of philosophy in connection with major social and intellectual movements. This is a fairly new literature, which emerged out of the scholarship known as "epistemologies of ignorance." The goal of this latter is to examine how ignorance is actively produced 
in the service of oppression and discrimination. Although "ignorance is often thought as a gap in knowledge," this scholarship directs us to the ways in which ignorance becomes a means for oppression (Sullivan \& Tuana, 2007, p. 1).If the goal of genocide denial is to create a social environment in which the perpetrators and their ideological followers do not become culpable, we can conclude that genocide denial can be considered as a form of actively distributed ignorance with a specific political agenda of making invisible the harm that was done. In light of this, we know that educational curricula that silence or distort historical evidence as well as criminalization of public opinions that recognize the genocide become the most frequently used political tools. To consider genocide denial as a form of epistemic justice (and/or as portraying an epistemology of ignorance) let us review the following question: How does genocide denial figure within the vocabulary of epistemic injustice? What is epistemologically unjust about genocide denial?

According to Linda M. Alcoff (2007) there are different ways to understand how ignorance operates. One view is that ignorance "should be understood as contextual" (Alcoff, 2007, p. 43). The claim is that ignorance should always be understood in terms of the individual's relation with the topic in question. For example, I may be very knowledgeable about other topics in Ottoman history, but I could still deny the existence of the Armenian genocide due to my lack of expertise with regard to that specific issue. According to this view, ignorance is not about the total lack of information but rather is contextual. The ignorance about specific topics result from the context in which the individual belongs. And since contexts are politically and socially formed, we can understand collective ignorance (as in the case of Armenian genocide) not necessarily as a fault of the individual but rather as a systematically and actively invested false-knowledge. Collective ignorance about the Armenian genocide is a form of epistemic injustice because it creates a social environment where the relationship between past violence and current violence cannot be understood. In other words, collective ignorance and denial prevents us from the ability to understand current state of affairs. We can address this issue further through Gaile Pohlhaus' study. Pohlhaus differentiates three types of epistemic injustice: 1) discrediting knowers and silencing a particular kind of knowledge; 2) distortion of understanding a phenomenon; and 3) using epistemic practices and institutions to produce the first two forms of injustice. (Pohlhaus, 2017, p.13). According to this taxanomy, the case of genocide denial applies to all three types of injustice. First of all, genocide deniers claim that survivors and their kin do not speak the truth; hence, they discredit the testimonies of the victims of genocide and accuse them of lying about the event. In some cases (as in the case of the Armenian Genocide), this silencing and prevention of public acknowledgement of the genocide extends to the failure of accountability, where perpetrators remain unknown and therefore not culpable. In these situations, if the survivors continue to reside in the country of origin where the genocide took place, they may face further violence and be victims of racist slurs and physical violence. The prevention of knowledge about a historical event such as a genocide, which shapes the racial and religious outlook of a country, has major ethical and political consequences, one of which is not being able to understand the suffering of one's fellow citizens. This corresponds to the second type of epistemic injustice that Pohlhaus detects. Furthermore, by using educational institutions and school curricula to spread false information about historical events, governments attempt to secure the inaccessibility of truth, and hence, enable a social environment where emotions of hatred towards the survivor group become widespread. Although effects of denial immediately and most specifically concern the targeted group, they also have an large impact on other minority communities and citizens.

\section{Conclusion}

Is genocide denial a form of evil or a type of epistemic injustice? In this paper, I demonstrated that two distinct scholarly attempts provide effective vocabulary for understanding the phenomenon of genocide denial. Perpetrators are often indifferent to the magnitude of the injury that they have caused. Hence following Card's theory of evil, I suggested that we must focus on the suffering of the victims because of the "magnitude gap" in the perception of the harm that was done. Furthermore, I concluded along with Ophir that genocides should be considered as "superfluous evils." That is to say, deniers' attempts to justify genocidal acts by resorting to the language of "national security threat" should be guarded against. In connection, I have also addressed the literature on epistemic injustice, which, I argued, can provide an effective lens through which we can assess the phenomenon of genocide denial. This literature provides various frameworks to assess the effects of genocide denial as forms of injustices that take place at the everyday level.

\section{References}

[1] Alcoff, L.M. (2007). Epistemologies of Ignorance, Three Types. In Shannon Sullivan \& Nancy Tuana (eds.). Race and Epistemologies of Ignorance. Albany: SUNY.

[2] Arendt, H. (1972). Lying in Politics. Crises of the Republic, New York: Harcourt Publishing.

[3] Card, Claudia. (2002). The Atrocity Paradigm, A Theory of Evil, New York: Oxford UniversityPress. 
[4] Caruth, C. (2010), Lying and History. In Berkowitz R., Keenan T., Katz J. Thinking in Dark Times: Hannah Arendt on Ethics and Politics, New York: Fordham University Press.

[5] Hovannisian, R. G. (1994). Etiology and Sequelae of the Armenian Genocide. In GeorgeJ. Andreopoulos (ed.). Genocide: Conceptual and Historical Dimensions, Philadephia: University of Pennsylvania Press.

[6] Kévorkian, R. (2011). The Armenian Genocide, A Complete History, New York: I.B. Tauris.

[7] Kidd, I. J., Medina, J. Pohlhaus Jr., G. (eds.). (2017). Introduction. The Routledge Handbook of Epistemic Injustice, New York: Routledge.

[8] Klein H. \& Kogan I. (1986). Some Observations on denial and Avoidance in Jewish Holocaust and PostHolocaust Experience. In E. L. Edelstein, Donald L. Nathanson, Andrew M. Stone (eds.), Denial: A Clarification of Concepts and Research, New York: Plenum Press.

[9] Lifton, R. J. (1986). The Nazi Doctors: Medical Killing and Psychology of Genocide, New York: Basic Books.

[10] Mamigonian,M. (2013). Scholarship, Manufacturing Doubt and Genocide Denial. The Armenian Weekly April Issue.

[11] Milburn, M A. \& Conrad, S. D. (1996). The Politics of Denial, Cambridge: MIT Press.

[12] Moeses, R. (1989). Denial in Political Process. In E. L. Edelstein, Donald L. Nathanson, Andrew M. Stone (eds.), Denial: A Clarification of Concepts and Research, New York: Plenum Press.

[13] Ophir, Adi. (2005). The Order of Evils, Toward an Ontology of Morals, New York: Zone Books.

[14] Pohlhaus, G. (2017). Varieties of Epistemic Injustice. In lan James Kidd, José Medina, Gaile

[15] Pohlhaus Jr. (eds.). The Routledge Handbook of Epistemic Injustice, , New York: Routledge.

[16] Smith, R. W. (2006.). The Significance of the Armenian Genocide after Ninety Years. Genocide Studies and Prevention Journal 1, 2: pp. i-iv.

[17] Smith, R. W., Markusen, E.,\& Lifton, R.J.(1999). Professional Ethics and the denial of Armenian Genocide. In Richard G. Hovannissian (ed.) Denial and Remembrance, The Case of the Armenian Genocide, , Detroit: Wayne State University Press, 1999.

[18] Sullivan S. \& Tuana N. (2007). Introduction. In Shannon Sullivan \& Nancy Tuana (eds.). Race and Epistemologies of Ignorance. Albany: SUNY.

[19] Suny, R. G. \& Göçek, F.M. (2011). Introduction: Leaving it to the Historians. In Ronald Grigor Suny, Norman M. Naimark (eds.) A Question of Genocide, New York, Oxford University Press.

[20] Türkmen-Dervişoğlu, Gülay (2013), "Coming to terms with a difficult past: the trauma of the assassination of Hrant Dink and its repercussions on Turkish national identity," Nations and Nationalism 19 (4): 674-692. 